\title{
Model of Risk Reduction Behavior and Financial Performance Escalation of Islamic Bank in Indonesia
}

\author{
Ahmad ROZIQ1, Siska Ayu ZUMAROH², Whedy PRASETYO ${ }^{3}$, Arnis Budi SUSANTO ${ }^{4}$ \\ ${ }^{1}$ University of Jember, JI. Kalimantan no. 37 Kampus Tegal Boto Jember , East Jawa, Indonesia \\ Email: ahmdroziq.feb@unej.ac.id \\ ${ }^{2}$ University of Jember, Jl. Kalimantan no. 37 Kampus Tegal Boto Jember , East Jawa, Indonesia \\ Email: siskaayzum28@gmail.com \\ ${ }^{3}$ University of Jember, Jl. Kalimantan no. 37 Kampus Tegal Boto Jember, East Jawa, Indonesia \\ Email: whedy.prasetyo@unej.ac.id \\ ${ }^{4}$ University of Jember, Jl. Kalimantan no. 37 Kampus Tegal Boto Jember , East Jawa, Indonesia
} Email: arnis.feb@unej.a.id

\author{
Received: 06.06.2021 Accepted: 28.08.2021 Published: 22.10.2021 $\quad$ DOI: $\underline{\text { 10.47750/QAS/22.184.15 }}$
}

\begin{abstract}
This study aims to examine and analyze the effects of: (a) capital structure on risk; (b) risk intermediary function; (c) operational efficiency against risk; (d) capital structure for financial performance; (e) intermediation function for financial performance; ( $f$ ) operational efficiency on financial performance and $(g)$ risk to financial performance. Quantitative research approach. This type of research is explanatory research. This study uses secondary data on the financial statements of Islamic banks in Indonesia for the 2014-2018 period with a purposive sampling technique from 14 Islamic banks in Indonesia so that a total sample of 60 was determined during the 2014-2018 observation. The research model used path analysis with regression using SPSS analyzed. The results of the study found that (a) the relationship between capital structure has no significant effect on risk; (b) the intermediation function has a significant and positive effect on risk; (c) operational efficiency has a significant and positive effect on risk; (d) capital structure has no significant effect on financial performance; (e) the intermediation function has no significant effect on financial performance; (f) operational efficiency has a significant and negative effect on financial performance; $(g)$ risk does not have a significant effect on financial performance.
\end{abstract}

Keywords: risk, efficiency, financial performance, intermediation function, capital structure

\section{Introduction}

According to Law No. 21 of 2008 concerning Sharia Banking, Islamic banking is everything that concerns sharia banks and sharia units, including institutions, business activities, as well as methods and processes in their business activities. The main objective of Islamic banking is as an effort for Muslims to underlie all aspects of their economic life based on the Al-Quran and Sunnah (Antonio, 2008). In carrying out its intermediary function, Islamic banks cannot be separated from the liquidity risk they will experience. Third party funds obtained by the bank will be channeled to parties in need. This will cause problems if the financing made by Islamic banks is congested or problematic. If this happens it will affect the income earned by Islamic banks, which will indirectly affect the decline in the level of profitability. In addition, Islamic banks must also ensure that third party funds can be withdrawn or withdrawn by the owner of the funds when the owner of the funds needs them.

Taken together, theoretical and empirical studies using agency theory as a theoretical framework suggest that conflicts of interest between managers and shareholders, managerial incentives, controlling shareholders' motives and the existing corporate governance structure in the firm have significant influence on the capital structure choices made by managers (Jensen \& Meckling, 1976; Berger et al., 1997; Faccio, Lang, \& Young, 2010; Vijayakumaran \& Vijayakumaran, 2019)

Regarding the empirical studies of CAR ratio's determinants, (Altunbas, Carbo, Gardener and Molyneux 2007; Dao \& Nguyen, 2020) stated that less risk incentives and more capital would be preferred when banks became inefficient; that implied a positive relationship between risks and capital. The level of capital adequacy is one of the things that must be considered by Islamic banks because the level of capital adequacy reflects the bank's ability to bear the risk of losses that may occur. The level of capital adequacy itself has been regulated by Bank Indonesia. A high level of capital adequacy can affect the increase in generating profitability. Apart from paying attention to the level of capital adequacy, operational efficiency of Islamic banks is also an important factor in the effort to achieve optimal levels of financial performance. Operational efficiency is the bank's ability to manage the portion of operating costs that must be spent as efficiently as possible and still maximize service to customers in order to generate maximum operating income (Khatimah, 2010). The 
high operational efficiency of Islamic banks indicates that income has also increased, thus affecting the increase in profitability. It stated that the company should disclose all its information to keep a good relationship with its stakeholders (Freeman, 1994; Tabash, 2019). Islamic finance, particularly Islamic banking, is a different model of financing which is based on equity not on debt.

The ratio of BOPO in Islamic Commercial Banks and Sharia Business Units in Indonesia is quite high. According to Islamic banking statistics published by the Financial Services Authority (OJK), in 2014 the BOPO ratio was $96.97 \%$ and in 2015 it had increased to $97.01 \%$. The high BOPO ratio certainly reflects that the level of operational efficiency of Islamic commercial banks in Indonesia is low, even though their assets are increasing. According to Rozak (2010: 3), if a bank asset increases, it will affect efficiency because the income received will increase so that BOPO will decrease.

Akintoye (2009) confirmed the role of business risk, taxes, managerial behavior or financial flexibility in the analysis of firm performance. He explained that since the capital structure is based on the trade-off between risk and expected return, these are crucial factors in determining a target capital mix. This target would guide companies towards an ideal mix of debt and equity that minimizes the cost of capital and maximizes the company value. Moreover, any changes made in the level of debt or equity will modify the firm's value. According to tax benefits it is expected that under the tax burden, companies would borrow more in order to obtain a higher performance (Vătavu, 2015).

Capital Adequacy Ratio (CAR) is the ratio of bank performance to measure the adequacy of capital owned by the bank to support assets that contain or generate risk. Capital is one of the important factors in developing a business business and accommodating the risk of loss, the higher the CAR, the stronger the bank's ability to bear the risk of any risky loans / productive assets.

The Financing to Deposit Ratio (FDR) is a tool to measure the extent to which a bank is able to pay for depositors' withdrawals whose funds have been channeled directly by the bank to the public by means of loans. FDR will show the level of the Bank's ability to channel third party funds collected by the Bank concerned

BOPO is a comparison between operating costs and operating income in measuring the level of efficiency and ability of a bank in carrying out its operations. The smaller the BOPO ratio means the more efficient the operational costs incurred by the bank concerned and any increase in operating income will result in reduced profit before tax which will ultimately reduce the profit or profitability $(\mathrm{ROA})$ of the bank concerned.

NPF is a ratio used to measure a bank's ability to measure the risk of default on loan repayments by debtors (the party receiving financing). The smaller the NPL (NPF), the smaller the loan risk (financing) borne by the bank. Banks in providing loans (financing) must analyze the ability of the debtor (financing recipient) to pay back their obligations. After the loan (financing) is granted, the bank is obliged to monitor the use of the loan (financing funds) and the ability and compliance of the debtor in fulfilling their obligations.

Financial performance on the profitability ratio using return on assets is calculated by comparing the Profit (before tax) with the total assets owned by the Bank in a certain period multiplied by $100 \%$, the result is also expressed in percent (\%). To get the ratio calculation results to be closer to the actual conditions, the capital or assets position is calculated on average during the calculation period. Bank is an organization that combines human effort and financial resources to carry out the functions of the bank in order to serve the needs of the community and to make a profit for the owners of the bank
(Hempel, 1999). Banking profits obtained through bank intermediation process. Analysis of profitability needs to be done to measure the level of business efficiency and profit achieved by a bank. Ratio commonly used to measure and compare the performance of profitability is ROA. ROA is the major ratio used in analyzing bank profitability. ROA is used to assess the ability of bank management in managing all bank assets to create revenue in the form of profit is calculated by comparing net income to average total assets. The higher of the ROA, so better of the bank's management to generate profits (Buchory, 2014).

Some think that performance is the total market value of a firm or the sum between market value of equity and value of equity options (Cole \& Mehran, 1998; Merz \& Yashiv, 2007). Others consider that company value refers to more than market capitalization, taking into consideration the value of firm's operation assets (Allen \& Rai, 1996; Ang et al., 2000; Mehran, 1995). Either way, firm performance reflects how effectively companies manage their resources. There is a multitude of capital structure indicators that influence the firm performance and profitability. Previous studies report a positive relationship between short-term debt and total debt and performance, but a negative impact from long-term debt to profitability expressed through return on equity (Abor, 2005). A negative correlation between leverage and performance, described by the ratio of earnings before interest and tax to total assets, was found in the Chinese firms (Huang and Song, 2006; Chakraborty, 2010). There are also studies such as Ebaid (2009), where no significant impact was found between capital structure choices and performance. Studies analyzing the impact of financing decisions on performance and profitability usually employ some of the most relevant capital structure determinants.

Based on the background described, the research was conducted to determine the Model of Risk Reduction and Financial Performance Escalation of Islamic banks in Indonesia "so that this research can identify several problems related to capital structure, intermediation function, operational efficiency on financial performance which will be mediated by risk.

\section{Literature Review Pecking Order Theory}

This theory describes a level in the company's funding decisions which indicates that the company prefers to use internal equity (assets owned by the company) in investment financing and implementation. This theory is built on several assumptions that emphasize the importance of sufficient financial slack in the company to fund the company's business with internal funds. The level of this funding decision starts with internal equity obtained from retained earnings and depreciation, then debt originating from creditors' loans, then the final decision to use external equity is obtained from issuing new shares (Myers and Majluf 1984)

\section{Agency Theory}

Banking agency problems are related to the separation of ownership from control that arises because the owner cannot supervise the company's activities from time to time, so that the owner delegates control authority in terms of business management as well as decision making to managers. The agency problem in the Islamic banking product scheme occurs because of the presence of asymmetric information. In this case the bank as a sahib al mal gets less information about the state of the business it has financed compared to customers as mudarib who have a lot of information and know about the business it is running. Meanwhile, financing with mudharabah 
and musharakah contracts in Islamic banking has a high risk because the rate of return or income to be obtained between the bank and the customer is uncertain. Islamic banks can only predict the income received from the process of channeling funds for this financing through gathering information when the customer selection process and the business to be financed are carried out.

This research was conducted by Adiputra (2017) which discussed the effects of CAR, NPF, FDR, and OEOI on profitability. Which results in the conclusion that CAR has no effect on ROA of Islamic banks, NPF has a negative and significant effect on ROA, FDR has no effect on ROA, and BOPO has a negative and significant effect on ROA. Another study was conducted by Khatimah (2010) which discussed the effect of CAR and BOPO on ROA. The results of the research conducted by khatimah, namely that CAR has a significant effect on ROA and BOPO has a negative and significant effect on ROA. A similar study was also conducted by (Nur'aini, 2017) with the results of the study that CAR does not have a significant effect on ROA, credit risk has no effect on ROA, operational efficiency has a significant and negative effect on ROA, and liquidity has a positive effect on ROA. (Setiawati et al., 2017) conducted research in the period 2011-2015 which resulted that $C A R$ had a significant and negative effect on ROA, NPF, had no effect on ROA, BOPO had a significant effect on ROA, and liquidity had no effect on ROA.

Ma'isyah and Mawardi (2015) conducted research on profitability with the CAR, FDR, BOPO and NPF variables. This study concluded that CAR has a significant effect on ROA, FDR has no effect on ROA, BOPO has a significant effect on ROA, and NPF has a significant effect on ROA. Purba (2011) in his research also concluded that CAR has no significant effect on ROA, FDR has a significant effect on ROA, and BOPO has no significant effect on ROA. Masdupi (2014) in his research also concluded that CAR has no significant effect on ROA, BOPO has a significant and negative effect, liquidity has no significant effect on ROA, and credit risk has a negative and significant effect.

(Yudawisastra et al., 2018) say that financial leverage creates financial risks. research of (Diyanti and widyarti 2012) proves that CAR has a significant effect on credit risk. The risk that a bank may face towards its liquidity condition is called liquidity risk (Machmud and Rukmana, 2010). Research conducted by Poetry and Sanrego (2011) found that when the FDR variable increases, the NPF will increase. has decreased. (Cole \& Mehran 1989; Susanti 2015) state that risk occurs when a bank operates less efficiently so that BOPO will increase. Syaifuddin (2005) found that there is a significant direct influence between operational efficiency variables and risk variables. (Adiputra, 2019) states that an adequate level of capital can protect a bank when it experiences losses from an unexpected operational activity. Research by (Khatimah 2010; Rois 2017; Maisyah and Mawardi 2015) proves that that CAR has a significant effect on ROA. According to Machfoedz (1999), low FDR level will reduce the level of profitability. Research conducted by (Nur'aini, 2017; Purba 2011) which proves that liquidity has a significant effect on ROA. According to Amilia (2005) high operating costs compared to operating income earned by Islamic banks will affect the financial performance of these Islamic banks. Research conducted by (Adiputra 2017; Khatimah 2010; Nur'aini, 2017; Masdupi 2014) found that BOPO has a significant effect on ROA. According to Taswan (2010:166), the higher the NPF ratio has an effect on the decrease in profits that will be obtained by Islamic banks, because of bad financing and the profit sharing that cannot be optimized. Research conducted by Adiputra (2017), Ma'isyah and Mawardi (2015) and Masdupi (2014) found that NPF has a significant effect on earnings performance.

\section{Methodology}

This type of research is explanatory research. Where this research is explanatory and aims to test hypotheses to strengthen or reject theories or hypotheses from the results of other existing research. According to Singarimbun and Effendy (1995: 4), explanatory research is research in the form of an explanation that highlights the clausal relationship between the research variables and tests the previously formulated hypotheses. According to Sugiyono (2016: 80 ) population is a generalization area consisting of objects or subjects that have certain qualities and characteristics that are determined by researchers to be studied and then drawn conclusions. The population to be observed in this study is all Islamic commercial banks registered in the Islamic Commercial Bank at Bank Indonesia during the observation year, namely 2014-2018. The data taken to examine the relationship between variables used data for five years, namely from 2014-2018. This study will use some Islamic commercial banks to be used as research samples. This sample was taken using purposive sampling technique. The technique used is the documentation technique. Documentation is a data collection technique used to obtain information and data required by documents. Data retrieval in this document is in the form of published financial statements that have been audited from 2014 to 2018. Path analysis is a development technique of multiple linear regression analysis. Path analysis is used to test how much contribution is shown by the path coefficient on each path diagram of the causal relationship between the variables $X_{1}, X_{2}, X_{3}$ on the variable Retherford (1993) defines path analysis as a technique used to analyze causal relationships. the effect that occurs in multiple linear regression analysis, whether exogenous variables affect endogenous variables, either directly or indirectly. According to Jonathan Sarwono (2011) path analysis is an analysis technique that is arranged based on a temporary order by using the jalous coefficient as a value in determining the magnitude of the influence of exogenous variables on endogenous variables. This path analysis model is used to analyze the pattern of relationships which aims to determine the direct and indirect effect of exogenous variables on endogenous variables. This test will be carried out using the help of the SPSS application.

\section{Results and Discussion}

Path Analysis for Structural Equations 1

The structural equation 1 in this research model is to determine the effect of capital structure, intermediation function, and operational efficiency together on risk. The results of the structural equation path analysis 1 are as follows. 


\section{GENERAL MANAGEMENT}

\begin{tabular}{|c|c|c|c|c|c|c|}
\hline \multicolumn{7}{|c|}{ Coefficients $^{\mathrm{a}}$} \\
\hline \multirow{2}{*}{\multicolumn{2}{|c|}{ Model }} & \multicolumn{2}{|c|}{$\begin{array}{l}\text { Unstandardized } \\
\text { Coefficients }\end{array}$} & \multirow{2}{*}{$\begin{array}{l}\text { Standardized } \\
\text { Coefficients } \\
\text { Beta } \\
\end{array}$} & \multirow[t]{2}{*}{$t$} & \multirow[t]{2}{*}{ Sig. } \\
\hline & & B & Std. Error & & & \\
\hline \multirow[t]{4}{*}{1} & (Constant) & -8.747 & 4.397 & & -1.989 & .053 \\
\hline & Capital Structure & -.076 & .042 & -.317 & -1.809 & .077 \\
\hline & Intermediary Fungtion & .049 & .024 & .307 & 2.089 & .042 \\
\hline & Operational Efficiency & .103 & .037 & .435 & 2.777 & .008 \\
\hline
\end{tabular}

Table 1: Path Analysis Result of Structural Equation 1

Based on the results of the path anlysis test for structural equation 1, the unstandarized beta results in the capital structure variable were -0.076 with a significant value of 0.077 , the intermediation function variable was 0.049 with a significant value of 0.042 , the operational efficiency variable was 0.103 with a significance value of 0.008 .
Path Analysis for Structural Equations 2

The structural equation 2 in this research model is to determine the effect of exogenous variables, namely capital structure, intermediation function, operational efficiency, and risk to endogenous variables, namely financial performance.

\begin{tabular}{|c|c|c|c|c|c|}
\hline \multicolumn{6}{|l|}{ Coefficients $^{a}$} \\
\hline \multirow[t]{2}{*}{ Model } & \multicolumn{2}{|c|}{$\begin{array}{l}\text { Unstandardized } \\
\text { Coefficients }\end{array}$} & \multirow{2}{*}{$\begin{array}{l}\text { Standardized } \\
\text { Coefficients } \\
\text { Beta } \\
\end{array}$} & \multirow[t]{2}{*}{$t$} & \multirow[t]{2}{*}{ Sig. } \\
\hline & B & Std. Error & & & \\
\hline \begin{tabular}{l|l}
1 & (Constant) \\
\end{tabular} & 32.980 & 3.536 & & 9.326 & .000 \\
\hline Capital Structure & -.005 & .034 & -.017 & -.163 & .871 \\
\hline Intermediary Function & -.030 & .019 & -.140 & -1.598 & .117 \\
\hline Operational Efficiency & -.316 & .031 & -.986 & -10.227 & .000 \\
\hline Risk & .104 & .114 & .077 & .917 & .364 \\
\hline
\end{tabular}

Table 2: Path Analysis Result of Structural Equation 2

Based on the results of the second regression equation in the table above, the following results are obtained:

1. Unstandarized beta on the capital structure variable is 0.005 with a significance value of 0.871 ;

2. Unstandarized beta on the intermediation function variable is -0.030 with a significance value of 0.871 ;

3. Unstandarized beta on the operational efficiency variable of -0.316 with a significance value of 0.000 ;

4. Unstandarized beta at risk of 0.104 with a significance value of 0.364

The complete results of the path equation in this study can be seen in the following figure.

After carrying out tests on both structural equations, the following conclusions can be drawn.

a) Based on table 4.2, it is known that capital structure has no significant effect on risk with a regression coefficient of -0.076 and a significance value of $0.77>$ 0.05 .

b) Based on table 4.2, it is known that the intermediation function has a significant effect on risk with a regression coefficient of 0.049 and a significance value of $0.042<0.05$.

c) Based on table 4.2, it is known that operational efficiency has a significant effect on risk with a regression coefficient of 0.103 and a significance value of $0.008<0.05$. d) Based on table 4.3, it is known that the capital structure has no significant effect on financial performance with a regression coefficient of -0.005 and a significance value of $0.871>0.05$

e) Based on table 4.3, it is known that the intermediation function has no significant effect on financial performance with a regression coefficient of -0.030 and a significance value of $0.117>0.05$.

f) Based on table 4.3, it is known that operational efficiency has a significant effect on financial performance with a regression coefficient of -0.316 and a significance value of $0.000<0.05$.

g) Based on table 4.3 it is known that risk does not have a significant effect on financial performance with a regression coefficient of 0.104 and a significance value of $0.364>0.05$.

\section{Determination Coefficient Test (R2)}

This coefficient aims to measure how far the model's ability to explain the variation of endogenous variables. This coefficient is indicated by the magnitude of $R 2$ between 0 and 1. If the value of $R 2$ is close to one, the exogenous variable almost provides all the information needed to predict the variation in endogenous variables. 


\begin{tabular}{l}
\begin{tabular}{|l|l|l|l|l|}
\hline \multicolumn{4}{|l|}{ Model Summary } \\
\hline Model & $\mathrm{R}$ & $\mathrm{R}$ Square & Adjusted R Square & Std. Error of the Estimate \\
\hline 1 & $.582 \mathrm{a}$ & .339 & .295 & 1.61726 \\
\hline
\end{tabular} \\
$\begin{array}{l}\text { a. Predictors: (Constant), Operational Efficiency, Intermediation Function, Capital Structure } \\
\text { Source: Appendix 5. Hypothesis Test Output }\end{array}$ \\
\hline
\end{tabular}

Table 3: Adjusted R2 Test Results on Line 1

\begin{tabular}{|l|l|l|l|l|}
\hline \multicolumn{4}{|l|}{ Model Summary } \\
\hline Model & $\mathrm{R}$ & R Square & Adjusted R Square & Std. Error of the Estimate \\
\hline 1 & $.889 \mathrm{a}$ & .790 & .772 & 1.24804 \\
\hline $\begin{array}{l}\text { a. Predictors: (Constant), Risk, Intermediation Functions, Operational Efficiency, Capital Structure } \\
\text { Source: Appendix 5. Hypothesis Test Output }\end{array}$
\end{tabular}

Table 4: Adjusted R2 Test Results on Line 2

Based on the table above, there is an Adjusted R Square value of 0.772 on line 2 and 0.295 in the structural equation 1 . In structural equation 1 with a value of 0.295 this means that the influence of exogenous variables is represented by the capital structure, intermediation function, and operational efficiency on endogenous variables. represented by a risk of $29.5 \%$. While the remaining $70.5 \%$ is explained by other variables not examined in this study. On line 2, the Adjusted R2 value is 0.772 , this means that the effect is also greater. The influence of the variables of capital structure, intermediation function, operational efficiency, and risk on endogenous variables, namely financial performance of $77.2 \%$, then the variable of financial performance can be explained by variables of capital structure, intermediation function, operational efficiency, and risk by $77.2 \%$. the remaining $22.8 \%$ is explained by other variables not examined in this study.

\section{Discussions}

The results of the study using the path analysis test in table 4.2 show that the significance value is 0.053 which is greater than the significance value of 0.05 with a coefficient value of 0.076 . These results prove that the capital structure has no significant effect on risk. From these results, hypothesis $1(\mathrm{H} 1)$ is rejected and it is concluded that capital structure has no significant effect on risk. Meanwhile, in the $T$ test, to test the level of influence partially. The results of this study are consistent with research conducted by Marwan, et.al (2009) who in their research stated that capital structure has no effect on risk.

The results of the study using the path analysis test showed a significance value of 0.042 and a coefficient value of 0.049 . These results indicate that the significance value is smaller than 0.05 and indicates a significant influence on risk so that hypothesis 2 is accepted. From these results, it can be concluded that the intermediation function has a significant and positive effect on risk. The results of this study are consistent with research conducted by Fayakun (2016) and Saragih (2015) which states that the intermediation function has a significant effect on risk.

The results of the study using the path analysis test showed a significance value of 0.008 with a coefficient value of 0.103 . These results indicate that the significance value is smaller than 0.05 which indicates an influence between operational efficiency and risk. It can be concluded that operational efficiency has a significant and positive effect on risk. These results are consistent which states that there is a significant direct effect between operational efficiency and risk.
The results of the path analysis test show that the significance value is 0.871 with a coefficient of -0.005 . The significance value which is higher than 0.05 proves that there is no significant influence between capital structure on financial performance. With this, hypothesis 4 is rejected and it is concluded that there is no significant influence between capital structure and financial performance. This indicates that an increase or decrease in the capital structure ratio does not have an impact on the increase or decrease in financial performance ratios. This is consistent with research conducted by Adiputra (2017), Purba (2011), Pravasanti (2018), and Masdupi (2014). which together conclude that the proxied capital structure using CAR does not have a significant effect on financial performance as proxied by ROA.

This CAR condition that does not affect ROA is due to the fact that Islamic commercial banks have not been able to optimally utilize their excess capital. This is indicated by the condition of the CAR ratio of Islamic commercial banks in the study sample which shows an average of $20.98 \%$. According to Bank Indonesia Regulation No. 15 states that Islamic commercial banks that have a CAR ratio above $14 \%$, it can be said that the Islamic bank is healthy and is in a level 5 risk profile. optimal for business development. The less than optimal use of capital will have an effect on reducing the potential to obtain maximum capital so that CAR does not have an effect on ROA.

The results of the research with the path analysis test showed a significance value of 0.117 with a coefficient value of -0.030 . The results of the significance value above 0.05 indicate that there is no significant effect. With these results, hypothesis 5 is rejected and it is concluded that the intermediation function does not have a significant effect on financial performance. This result is consistent with research conducted by Adiputra (2017), Rois (2017), Ma'isyah and Mawardi (2015), and Masdupi (2014) which states that the intermediation function proxied by using FDR has no significant effect on profitability which is proxied by using ROA. This intermediation function is the main function carried out by Islamic commercial banks so that it requires good management in order to generate maximum profitability. This intermediary function is inseparable from liquidity risk. This risk arises because some of the funds have been transferred to third parties. The emergence of risk in financing disbursement encourages Islamic commercial banks to choose the contract that has the lowest risk. If a sharia commercial bank prefers a consumptive murabahah contract to reduce the risk of financing, this condition will affect the profitability of Islamic commercial banks. Profits with a murabahah contract cannot be as optimal as compared to the musyarkah and mudharabah 
contracts. This is certainly able to explain the causes of FDR which do not affect the ROA of Islamic commercial banks.

The results of this study with the path analysis test showed that the significance value was 0.000 with a coefficient value of -0.316 . The significance value which is below 0.05 indicates a significant effect. These results prove that hypothesis 6 is accepted and it is concluded that the effect of operational efficiency on financial performance is a significant and negative effect. This is in accordance with research conducted by (Adiputra 2017; Susanti 2015; Khatimah 2010; 'Aini 2017; Rois 2017; Masdupi 2014) who in their respective studies state that operational efficiency which is proxied by BOPO has a significant and negative effect on profitability which is proxied by ROA.

The results of this study with the path analysis test showed that the significance value was 0.364 with a coefficient of 0.104 . The significance value that is above 0.05 indicates no significant effect so that hypothesis 7 is rejected. With these results it can be concluded that risk has no significant effect on financial performance. This is in accordance with research conducted by 'Aini (2017) and Rois (2017) which in their research said that risk did not have a significant effect on profitability.

\section{Conclusions}

The results of research on the effect of capital structure, intermediation function, operational efficiency, and risk on stdi financial performance at Islamic commercial banks registered with Bank Indonesia during the 2014-2018 period have been described in the research that has been carried out. four, it can be concluded from this study as follows: (a) capital structure has no significant effect on risk; (b) the intermediation function has a significant and positive effect on risk, (c) operational efficiency has a significant and positive effect on risk, (d) the capital structure does not have a significant effect on financial performance; (e) the intermediation function has no significant effect on financial performance; (f) operational efficiency has a significant and negative effect on financial performance; and $(\mathrm{g})$ risk does not have a significant effect on financial performance.

Based on the conclusions that have been made in the study, the researcher experienced several limitations in this study, namely as follows: (a) the method of sampling using purposive sampling made the sample from the study less able to generalize the population from the study because the research sample was only adjusted to the criteria the sample that the researcher wants and (b) the results of the Adjusted R2 study show that the variables of capital structure, intermediation function, and operational efficiency only have an effect on risk of $29.5 \%$, so it is suspected that there are other variables that may still affect risk that were not examined in this study. . Based on the research limitations that have been stated, the researchers provide suggestions, namely (a) further research can use other sample-taking methods that can generalize the population as a whole and (b) further research can add other variables that represent risks such as growth in financing, inflation, financial crisis, and the size of the bank or taking other ratios to measure risk other than credit risk.

\section{References}

[1] Adiputra, F. (2018). The Effect of CAR, NPF, FDR and BOPO on Profitability (ROA and ROE) in Shariah Public Banks. In Theses, State Islamic University Syarif Hidayatullah. Syarif Hidayatullah State Islamic University.
[2] Abor, J. (2005). The effect of capital structure on profitability: an empirical analysis of listed firms in Ghana. The Journal of Risk Finance, 6(5), 438-445. doi: 10.1108/15265940510633505

[3] Akintoye, I.R. (2009) Sensitivity of Performance to Capital Structure, Banking and Finance Letters, 1(1), pp.29-35

[4] Allen, F., Carletti, E., \& Marquez, R. S. (2009). Stakeholder Capitalism, Corporate Governance and Firm Value. SSRN Electronic Journal. doi: 10.2139/ssrn.968141

[5] Altunbas, Y., Carbo, S., Gardener, E. P. M., \& Molyneux, P. (2007). Examining the Relationships between Capital, Risk and Efficiency in European Banking. European Financial Management, 13(1), 49-70. doi: 10.1111/j.1468036x.2006.00285.x

[6] Ang, J. S., Cole, R. A., \& Lin, J. W. (2000). Agency Costs and Ownership Structure. The Journal of Finance, 55(1), 81-106. doi: 10.1111/0022-1082.00201

[7] Baker, M., \& Wurgler, J. (2002). Market Timing and Capital Structure. The Journal of Finance, 57(1), 1-32. doi: 10.1111/1540-6261.00414

[8] BERGER, P. G., OFEK, E., \& YERMACK, D. L. (1997). Managerial Entrenchment and Capital Structure Decisions. The Journal of Finance, 52(4), 1411-1438. doi: 10.1111/j.1540-6261.1997.tb01115.x

[9] Buchory, H. A. (2014). Analysis of the Effect of Capital, Operational Efficiency, Credit Risk and Profitability to the Implementation of Banking Intermediation Functions ( Study on Regional Development Bank All Over Indonesia in 2012). Academic Research International, 5(July), 440-457.

[10] Chakraborty, I. (2010). Capital structure in an emerging stock market: The case of India. Research in International Business and Finance, 24(3), 295-314. doi: 10.1016/j.ribaf.2010.02.001

[11] Cole, R. A., \& Mehran, H. (1998). The effect of changes in ownership structure on performance: Evidence from the thrift industry. Journal of Financial Economics. doi: 10.1016/S0304405X(98)00039-7

[12] DAO, B. T. T., \& NGUYEN, K. A. (2020). Bank Capital Adequacy Ratio and Bank Performance in Vietnam: A Simultaneous Equations Framework. The Journal of Asian Finance, Economics and Business, 7(6), 39-46. doi: 10.13106/jafeb.2020.vol7.no6.039.

[13] Diyanti, A., Endang T.W., 2012. Analysis of the Influence of Internal and External Factors on the Occurrence of NonPerforming Loans (Case Study of Conventional Commercial Banks Providing Home Ownership Credit Services for the Period of 2008-2011).

[14] El-Sayed Ebaid, I. (2009). The impact of capital-structure choice on firm performance: empirical evidence from Egypt. The Journal of Risk Finance, 10(5), 477-487. doi: $10.1108 / 15265940911001385$

[15] Effendy, M., Manurung, T., \& Mulyana, M. (2009). The Influence Of Capital Structure To Financial Risk Of Company. Unity Scientific Journal, 11 (1).

[16] Fayakun, Nuar Nanda. 2016. Factors Affecting the Level of Credit Risk in Banking Companies Listed on the Indonesia Stock Exchange 2009-2013. Thesis: Muhammadiyah University of Surakarta

[17] Faccio, M., Lang, L. H., \& Young, L. (2009). Pyramiding vs leverage in corporate groups: International evidence. Journal of International Business Studies, 41(1), 88-104. doi: $10.1057 / j i b s .2009 .33$

[18] Freeman, R. E. (1994). The Politics of Stakeholder Theory: Some Future Directions. Business Ethics Quarterly, 4(4), 409421. doi: $10.2307 / 3857340$

[19] Greuning, Hennie Van Iqbal, Zamir. Risk Analysis of Islamic Banking: Risk Analysis For Islamic Banks. 2011

[20] Shawk, (2008), Operational Efficiency a Brand Point Management Perspective, http://www.schawk.com

[21] Taswan. 2010. Banking Management, Concepts, Techniques, and Applications. Second Edition. Yogyakarta: UPP STIM 
YKPN.

[22] Hempel, G. H., Simonson, D. G., \& Coleman, A. B. (1994). Bank Management Text and Cases, Fourth Edition. New York: John Wiley \& Sons, Inc.

[23] HUANG, G., \& SONG, F. M. (2006). The determinants of capital structure: Evidence from China. China Economic Review, 17(1), 14-36. doi: 10.1016/j.chieco.2005.02.007

[24] Jensen, M. C., \& Meckling, W. H. (1976). Theory of the firm: Managerial behavior, agency costs and ownership structure. Journal of Financial Economics, 3(4), 305-360. doi: $10.1016 / 0304-405 \times(76) 90026-x$

[25] Khatimah, I. (2010). Effect of Capital Adequacy and Operational Efficiency on Profitability at PT. BPRS Amanah Ummah Leuwiliang Bogor. Thesis: UIN Syarif Hidayatullah Jakarta

[26] Kumala, P. A. S., \& Suryantini, N. P. S. (2015). The Influence of Capital Adequacy Ratio, Bank Size and Bi Rate on Credit Risk (NPL) in Banking Companies. E-Journal of Management of Udayana University, 4 (8).

[27] Machfoedz, M. (1999). The Effect of Monetary Crisis on the Efficiency of Public Companies on the Jakarta Stock Exchange. Indonesian Journal of Economics and Business, 14 (1).

[28] Masdupi, E. (2014). The Effect of Operational Efficiency on the Profitability of the Banking Sector. Journal of Business Management Studies, 3 (1), 18.

[29] Machmud, Amir and Rukmana. 2010. Islamic Banking: Theory, Policy and Empirical Studies in Indonesia. Jakarta: Erlangga

[30] Marwan Effendy, Tarida, and Mumuh Mulyana, The Influence of Capital Structure on Corporate Financial Risk. Unitary Scientific Journal. Vol 3 Number 11, January 2009.

[31] Ma'isyah, R., \& Mawardi, I. (2015). The Influence of Capital Adequacy, Intermediation Function, Operational Efficiency, and Problem Financing on Profitability (Studies on Islamic Banks for the Period January 2010 - July 2014). JESTT, 2 (3), $1-8$.

[32] Mehran, H. (1995). Executive compensation structure, ownership, and firm performance. Journal of Financial Economics, 38(2), 163-184. doi: 10.1016/0304405x(94)00809-f

[33] Mills, S. \& D. Schumann (1985). Managing credit risk to optimize banks' profitability: a survey of selected banks in Nigeria. Research Journal of Finance and Accounting, 4(4), 2222- 2847.

[34] Nur'aini, I. (2017). The Influence of Capital Adequacy, Credit Risk, Operational Efficiency and Liquidity on Profitability. In Scientific Publications.

[35] Poetry, Z. D., \& Sanrego, Y. D. (2011). Effect of Macro and Micro Variables on NPL of Conventional Banking and NPF of Islamic Banking. Tazkia Islamic Finance and Business Review, 6 (2), 79-104
[36] Pravasanti, Y. A. (2018). Pengaruh NPF dan FDR Terhadap CAR dan Dampaknya Terhadap ROA Pada Perbankan Syariah Di Indonesia. Jurnal IImiah Ekonomi Islam, 4(03), 148. doi: 10.29040/jiei.v4i03.302

[37] Purba, D. (2011). The Effect of Capital Adequacy, Liquidity, and Operational Efficiency on Profitability at PT Bank Muamalat Indonesia, Tbk. Thesis, 1-113.

[38] Retherford, Robert D. (1993). Statistical Models For Causal Analysis. Program on Population East-West Center, Honolulu, Hawaii.

[39] Setiawati, E., Rois, D. I., \& Aini, I. N. (2017). The Effect of Capital Adequacy, Financing Risk, Operational Efficiency and Liquidity on Profitability (Studies on Islamic Banks and Conventional Banks in Indonesia). Indonesian Accounting and Finance Research, 2 (2), 109-120.

[40] Salman, Kautsar Riza. 2012. Accounting for Islamic Banking based on Islamic PSAK. Jakarta: Permata Academy

[41] Saragih, N. (2015). Factors Affecting Working Capital Credit Risk for Regional Development Banks in Indonesia. Economics Development Analysis Journal, 4 (2).

[42] Sarwono. 2011. Youth Psychology. Revised Edition. Jakarta: Rajawali Press.

[43] Singarimbun, Masri and Sofian Effendi. 1995. Survey Research Methods. Jakarta: LP3ES.

[44] Sugiyono. (2016). Quantitative Research Methods, Qualitative and R \& D. Bandung: Alfabeta

[45] Syaifuddin, D. T. (2005). The Effect of Operational Efficiency on Market Share and Risk and Performance of National Private Commercial Banks in Indonesia. University of Airlangga.

[46] Susanti, N. (2015). Effect of Operational Efficiency Level on Business Risk and Its Impact on Financial Performance in Banks Listed on the Indonesia Stock Exchange for the Period 2011-2014. Journal of Accounting Research and Studies, 8 (2), 119-126.

[47] TABASH, M. I. (2019). An Empirical Investigation on the Relation between Disclosure and Financial Performance of Islamic Banks in the United Arab Emirates. The Journal of Asian Finance, Economics and Business, 6(4), 27-35. doi: 10.13106/jafeb.2019.vol6.no4.27

[48] Vătavu, S. (2015). The Impact of Capital Structure on Financial Performance in Romanian Listed Companies. Procedia Economics and Finance, 32, 1314-1322. doi: 10.1016/s22125671(15)01508-7

[49] Vijayakumaran, S., \& Vijayakumaran, R. (2019). Corporate Governance and Capital Structure Decisions: Evidence from Chinese Listed Companies. Journal of Asian Finance, Economics and Business, 6(3).

[50] Garlinia Yudawisastra, H., T. H. Manurung, D., \& Husnatarina, F. (2018). Relationship between value added capital employed, value added human capital, structural capital value added and financial performance. Investment Management and Financial Innovations, 15(2), 222-231. doi: 10.21511/imfi.15(2).2018.20 